\title{
Identification \& spectrophotometric quantification of dyes in the selected confectionery items available in the local markets of Peshawar, Pakistan
}

\author{
Fazia Ghaffar $^{1 *}$, Faiza Tauqeer ${ }^{2}$ and Rozina Rauf ${ }^{1}$ \\ 1. Department of Food \& Nutrition Sciences, College of Home Economics, University of Peshawar, KPK \\ 25120-Pakistan \\ 2. Department of Textiles \& Clothing, College of Home Economics, University of Peshawar, KPK 25120- \\ Pakistan \\ *Corresponding author's email: faziaghaffar@uop.edu.pk \\ Citation \\ Fazia Ghaffar, Faiza Tauqeer and Rozina Rauf. Identification \& spectrophotometric quantification of dyes in the \\ selected confectionery items available in the local markets of Peshawar, Pakistan. Pure and Applied Biology. \\ Vol. 9, Issue 3, pp1690-1700. http://dx.doi.org/10.19045/bspab.2020.90179

\begin{tabular}{llll}
\hline \hline Received: 08/01/2020 & Revised: 22/03/2020 & Accepted: 31/03/2020 & Online First: 08/04/2020 \\
\hline \hline
\end{tabular}

\section{Abstract}

The study aimed at analyzing the food colours added to various confectionery items vended at the local market of Peshawar. Samples of different types of candies, chocolate beans, fruit jellies, lollipops, sweetened and coated aniseeds and papadhs were analyzed for identification and quantification of the added synthetic food colors. Although majority of branded items contained permitted colors however some items were found to contain non-permitted colors. About $22 \%$ items were found with non-permitted colors. Ponceau 4R (20.9\%), sunset yellow (18.7\%), tartrazine (16.7\%), and brilliant blue (14.6\%) were the most common dyes identified. Majority of the branded items contained different dyes within the permissible limits however, some non-branded items contained higher concentrations of Carmoisine (375.0 \pm 0.9 and $364.8 \pm 0.68 \mathrm{mg} \mathrm{kg}^{-1}$ ) against the permitted limit of $50 \mathrm{mg} \mathrm{kg}^{-1}$. Tartrazine was also found to be higher in non-branded items. The concentrations of naphthol yellow $(312 \pm 10.43$ and $812 \pm 21.07 \mathrm{mg} / \mathrm{kg}$ ) was found to be higher in the non-branded items. The concentrations of brilliant blue FCF were quite higher in some items. The use of green FCF and green $\mathrm{S}$ is a matter of food safety as these dyes are phased out in some developed countries. It is concluded that constant vigilance is needed to ensure that local manufacturers comply with the food laws and regulations of food colors. Constant supervision is direly needed not only in terms of nonpermitted food colors but also in the control and limits of permitted food colors. Moreover, mass awareness regarding consumption of colored food items is also needed particularly among young children.

Keywords: Concentrations; Confectionery items; Non-permitted colours; Permitted colours; Permissible limits; Synthetic food dyes

\section{Introduction}

Food manufacturers add a variety of additives to food products to enhance taste, appearance, flavor and other attributes [14]. Colour is a vital constituent of food probably because it is the first quality being perceived by the senses $[5,6]$. Food colour is any dye, pigment, or any other substance that is added primarily for restoring or adding colour during processing [7]. These colours are also used to enhance or optimize the colour of the end products [8]. Food 
colours can be divided into four classes i.e. natural, natural identical, synthetic, and inorganic colours [7]. These colours can also be categorized as permitted and nonpermitted food colours [9].

In recent years many synthetic dyes have been increasingly used to substitute natural colours or to achieve certain desirable qualities such as improved appearance, high colour intensity, colour stability and uniformity [10-14]. Compared to natural colours, these synthetic dyes are low in cost, resistant to light, temperature, oxygen, $\mathrm{pH}$ changes, and can be used without further processing [15]. Most of these synthetic dyes are the derivatives of coal tar and are synthesized from aminobenzene compound as azo group [16]. These dyes are widely used in many foods such as bakery products, confectioneries, jellies and beverages [17].

These colourants have been shown to cause intoxication and can cause a number of allergic reactions such as migraine, blotting, nettle rash, itching, blurred vision, rhinitis, and water retention [18]. These dyes are also associated with carcinogenicity, immune system disorders, decreased WBC and lymphocyte count and vitamin B6 deficiency [19]. They also cause anemia, sleep disturbances, liver and kidney ailments and hyperactivity in children $[2,10,11,20-22]$. The use of non -permitted colours and the indiscriminate use of permitted colours are not safe and can pose a serious public health risk among different age groups [23-24].

A large number of food laws exist in Pakistan but most them deal with the control of production, distribution, supply of food, profiting and hoarding. The current study aimed at the identification and quantification of food colours used in local confectionery items commonly consumed by children.

\section{Materials and methods}

A sample of forty-eight different types of branded and unbranded confectionary items were collected randomly from the local whole sale market "Peoples Mandi" of
Peshawar City. The sample consisted of hard candies, soft chewable candies, chewing gums, fruit jellies, coloured aniseeds, lollypops, papadh, and soft chocolate candies covered with hard coloured sweetened coatings. The samples were divided in to two categories branded and unbranded i.e. the one that fulfilled all the requisite information of some company name and a label (branded) and the items that either were sold loose (unpacked) or were packed by the sellers or though carried the name of the brand but no trade name and a label (non-branded).

\section{Standards and reagents}

Standard food dyes ponceau 4 R C-I 16185 (E 123, FD \& Red No.2), Carmoisine-C-I 14720 (E 122 EXT-D \& C Red No. 1), Tartrazine C-I-19140 (E 102 FD\&C Yellow No. 5), Sunset Yellow FCF C-I-15985 (E 110 FD \& C Yellow No. 6), Brilliant blue FCF C-I 42090 (E-133 FD \& C Blue No. 1 and D\&C Blue No. 4), Green S.L.I. 44090 (E-142 Lissamin Green, Acid Brilliant Green BS, and Wool Green BS) were purchased from Sigma Aldrich. All the other solvents and reagents were of analytical grade.

\section{Sample preparation}

Approximately 10 grams each of the grinded sample was thoroughly mixed in $50 \mathrm{ml}$ of $2 \%$ ammonia in $70 \%$ alcohol solution. The mixture was allowed to stand for an hour. In order to settle down starch and sugars in the samples the solutions were warmed on water bath for 3-5 minutes. The aliquot was then centrifuged at $1500 \mathrm{rmp}$ and the upper separated layer was allowed to evaporate on hot water bath. The residue was diluted later with $30 \mathrm{ml}$ of acetic acid solution for spectrophotometric determination.

\section{Colour extraction}

The pretreated samples were acidified with $2.0 \mathrm{ml}$ of $2 \mathrm{M}$ glacial acetic acid, an equal amount of distilled water. A $5.0 \mathrm{~cm}$ length conditioned pure sheep wool thread was immersed in each sample. These were kept in a water bath for 1 hour for the colour to be adsorbed onto the wool. The wool 
threads were later removed from the solutions and washed with running tap water. Afterwards the threads were soaked again in $2.0 \mathrm{ml}$ of $2 \mathrm{M}$ ammonia solution with an equal amount of distilled water and kept in a water bath until the wool threads were decolorized. The wool threads were removed and the solutions were concentrated by evaporation in a water bath. Some of the extracted colours along the confectionery samples are presented as (Figs. 1-20) here.

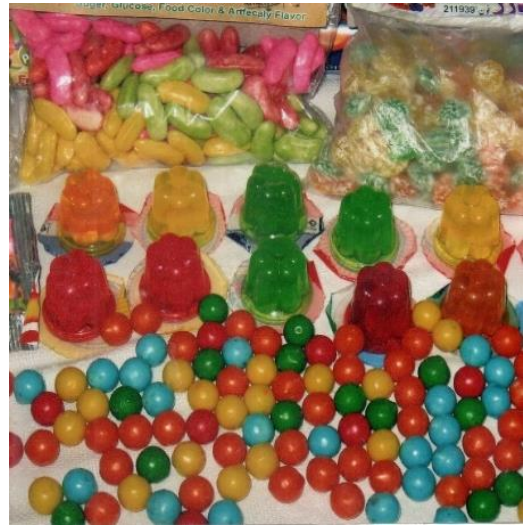

Figure 1. Unbranded confectionery samples

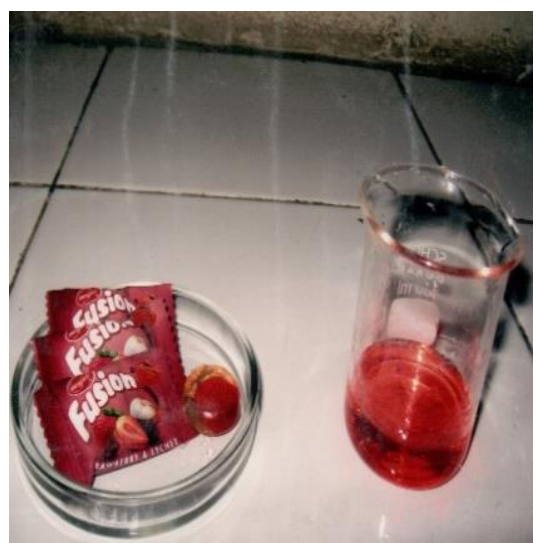

Figure 4. Hard candy extracted colour ponceau 4R

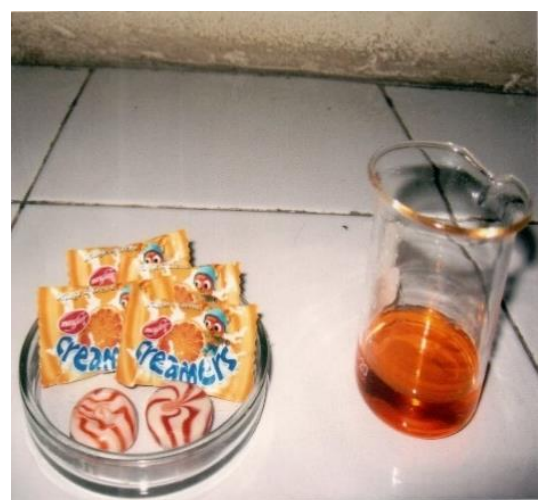

Figure 7. Candy sunset yellow FCF

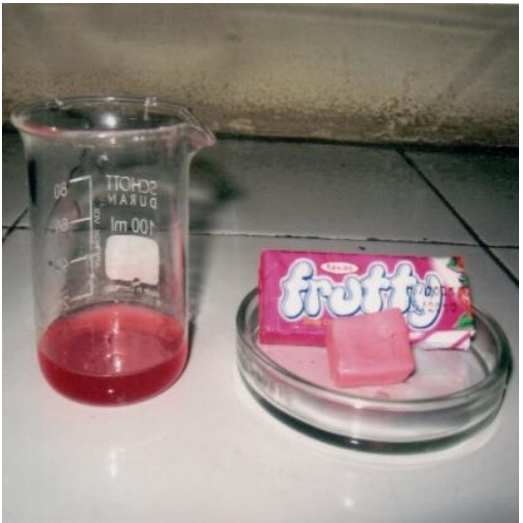

Figure 2. Chewing gum extracted carmoisine

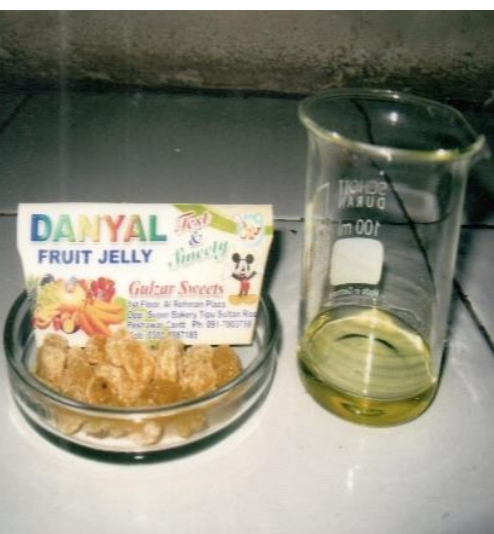

Figure 5. Fruit jelly extracted colour tartrazine

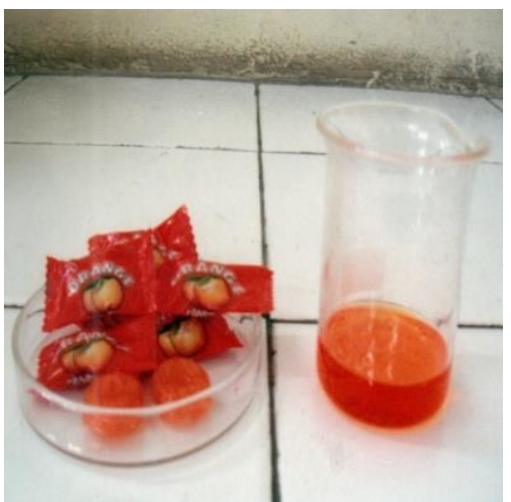

Figure 8. Candy extracted colour quinoline yellow

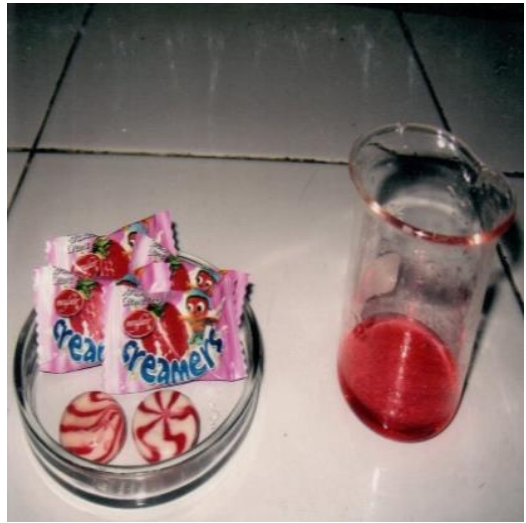

Figure 3. Hard candy extracted colour ponceau 4R

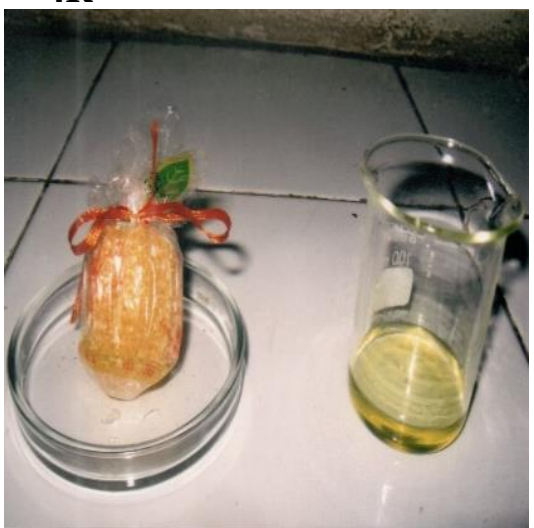

Figure 6. Fruit jelly extracted colour tartrazine

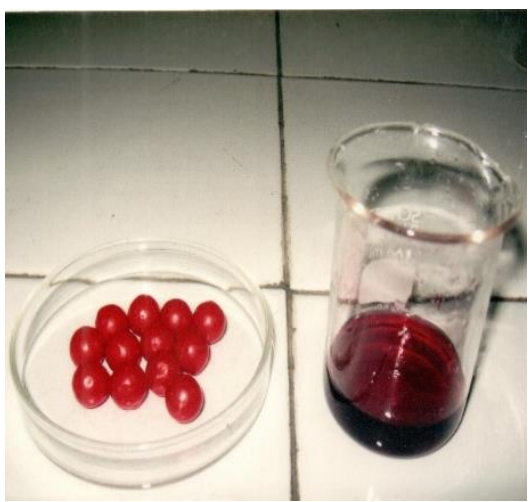

Figure 9. Chewy balls ponceau $4 R$ 


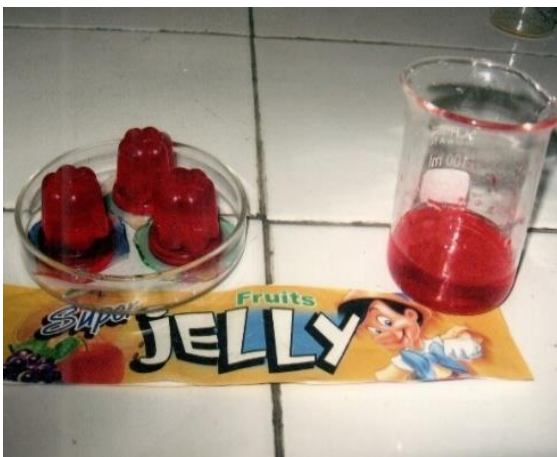

Figure 10. Fruit jelly ponceau $4 R$

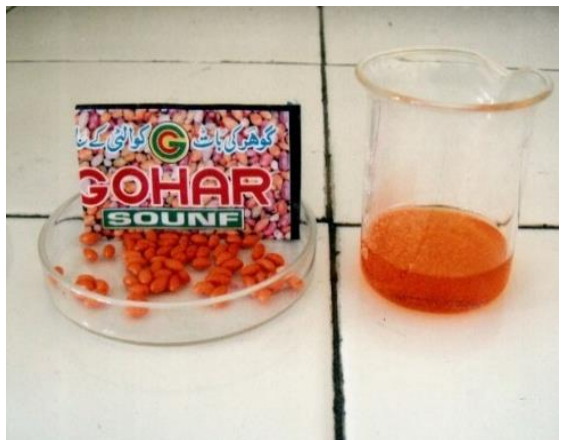

Figure 13. Aniseeds extarcted colour sunset yellow FCF

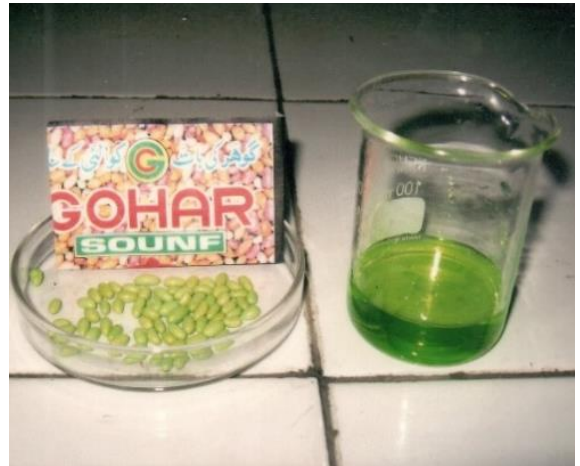

Figure 16. Aniseeds green FCF

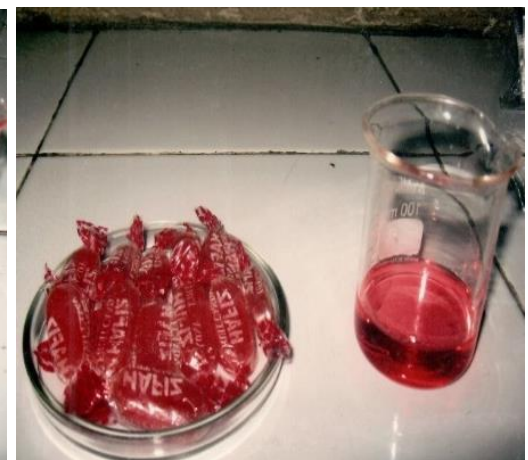

Figure 11. Chewy candy carmoisine

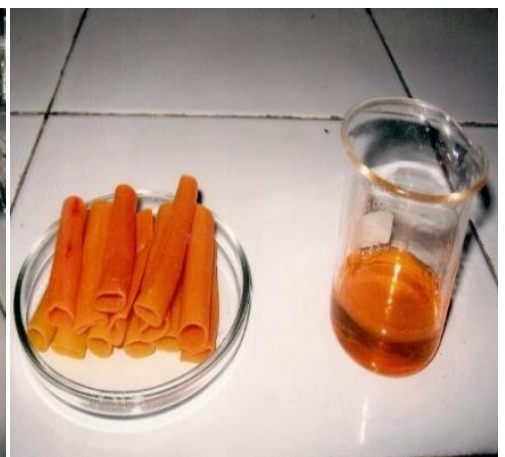

Figure 12. Papdh extracted colour nephthol vellow

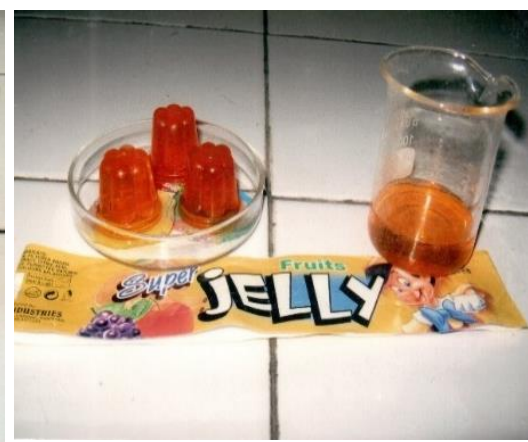

Figure 14. Fruit Jelly extracted colour sunset yellow FCF

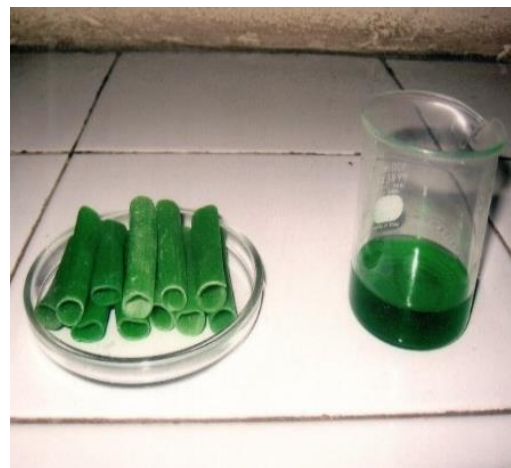

Figure 17. Papdh extracted colour green FCF

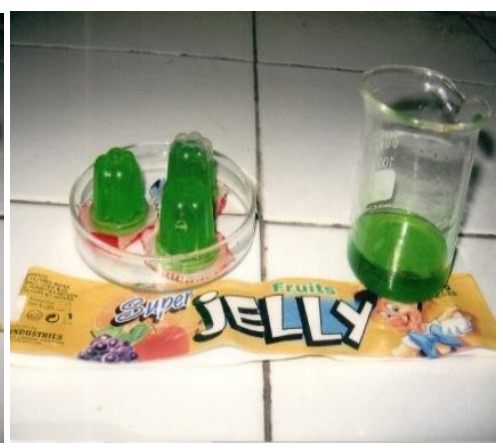

Figure 15. Fruit jelly extracted colour tartrazine

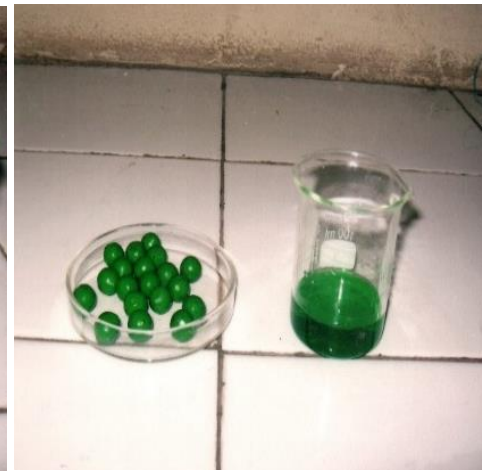

Figure 18. Chewy balls extracted colour brilliant blue FCF

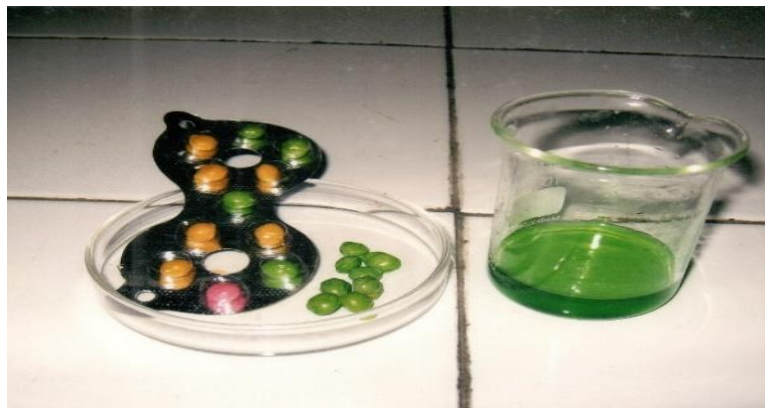

Figure 19. Choco beans extracted colour brilliant blue FCF

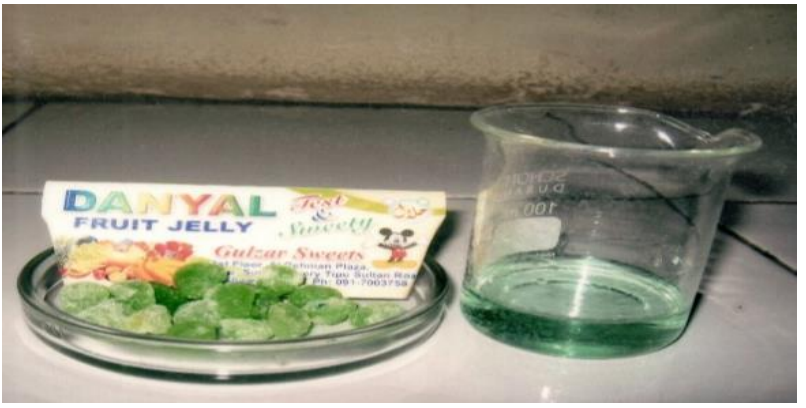

Figure 20. Soft candy extracted colour tartrazine 


\section{Identification and quantification of colours \\ Preparation of standard curves}

Stock solutions of the standards were prepared by dissolving $10 \mathrm{mg} / 1000 \mathrm{~mL}$ of pure standard in deionized water. A series of working solution were prepared i.e. 0,1 , $2,3,4$ and $5 \mathrm{~mL}$ from stock solution into $50 \mathrm{~mL}$ volumetric flasks and the volume was made with buffer solution to make 0 $\mathrm{mg} / 50 \mathrm{~mL}$ (blank), $0.1 \mathrm{mg} / 50 \mathrm{~mL}$, $0.2 \mathrm{mg} / 50 \mathrm{~mL}, 0.3 \mathrm{mg} / 50 \mathrm{~mL}, 0.4$ $\mathrm{mg} / 50 \mathrm{~mL}$ and $0.5 \mathrm{mg} / 50 \mathrm{~mL}$ solutions of known concentrations.

\section{Spectroscopic analysis}

The absorption maxima and percent concentration of dyes in the samples were determined by UV 1700 spectrophotometer (Shimadzu Japan). The absorption maxima of each standard were obtained between $190-1100 \mathrm{~nm}$. The spectra and $\lambda$ max value of samples and standards were compared with each other. The color value (color intensity) was measured from the UV absorbance. A plot of absorbance versus concentration of the known solutions (expressed as the concentration in $\mathrm{mg}$ of colour per $50 \mathrm{~mL}$ of solution) by the BeerLambert Law plot. Later the concentrations were converted to $\mathrm{mg} / \mathrm{kg}^{-1}$ and the means and standard deviations were calculated with Microsoft Excel

\section{Results and discussion}

Food colours, traditionally, are used to improve the appearance of the final product. In young children food selection is strongly affected by bright colours of food products. Research on the colour additives is a fundamental need these days since such additives are frequently used by young children. Among the low-income populations and rural areas lack of awareness and low literacy tend to motivate children to buy comparatively low cost, unpacked and unbranded chewing gums, candies, lollipops, papadh and other such sweetened confectioneries. Determination of the quality and quantity of colorants are the main requisites for the health of these young children. The current study revealed that $27 \%$ type of branded and $21 \%$ of unbranded selected samples (Graph 1) contained synthetic colours of some type. These findings are comparable to the findings of a study carried out at Karachi and Sri Lanka [16, 25].

Summary of the dyes identified (Table 1) showed that confectionery samples consisted of approved colours ponceau 4R, carmoisine, tartrazine, sunset yellow, quinoline yellow, brilliant blue FCF. Some banned dyes such as naphthol yellow, fast green FCF, and green $S$ were also identified within the samples collected.

In order to identify further the distribution of the permitted and non-permitted colours among the selected items (Graph 2 \& 3) indicated that $4 \%$ candies, $4 \%$ fruit jellies, $2 \%$ chocolate beans and $01 \%$ chewing gums contained non-permitted/banned colourants. Similar findings were also found by Saleem et al. who identified $11 \%$ of food samples and $4 \%$ of beverages with non-permitted colours in Karachi city [16]. Such dyes are unfit for human consumption and shall be worked out further based on time series studies in order to identify the type of colours used. In another study conducted at Allahabad, India nonpermitted Metanil yellow and malachite green in cake and ice cream in the local samples were identified [2]. Similarly, among 70 food items in Arak, Iran, $80 \%$ of the samples contained artificial colour additives that are banned as per by the National Iranian Standards [10]. Another study conducted by Farzianpour et al. showed that $6.52 \%$ of the pastry, poolak, and rock candy samples at Shahr-e-kord City, Iran, contained forbidden artificial food colours [11]. In a study conducted at Rawalpindi Cantt it was found that among 73 samples of sweetmeats and confectioneries, $\quad 46.57 \%$ contained nonpermitted colours [6]. The current study, therefore, creates a dire need to assure food safety and quality in the use of food colours in confectionery items locally. 
The percent distribution of different synthetic dyes within the studied samples showed that highest percentage of items contained ponceau 4R (20.9\%) followed by sunset yellow (18.7), tartrazine (16.7), brilliant blue FCF (14.6), and carmoisine (12.5). the samples containing fast naphthol yellow, green $\mathrm{FCF}$, green $\mathrm{S}$ were $4.2 \%$, $6.3 \%$, and $2.08 \%$ respectively. The presence of these banned colours though were found to be low but they may pose some serious health hazards to young children. Naphthol yellow $S$ is an organic compound that is a dye. It is a derivative of 1-naphthol. At one time it was a popular food colorant but was delisted in 1959 in the U.S. It is used in microscopic or electron microscopic examination of cells and tissues to give contrast and to highlight particular features of interest, such as nuclei and cytoplasm. Both green FCF and Green $S$ are banned internationally due to their chronic toxicity, genotoxicity, and carcinogenicity [27].

The content of red dyes determined (Table 2) showed that ponceau $4 R$ was highest in hard candies with a liquid filled center (153 $\mathrm{mg} \mathrm{kg}{ }^{-1}$ ) followed by other hard candies. All these concentrations were within the permissible limits. The concentration of carmoisine was higher in the fruit jellies followed by chewing gums. Non-branded showed very higher concentrations in all the items. The concentrations of yellow dyes (Table 3) showed quinoline yellow being the most common dye within the branded items while tartrazine was within the permissible limits in the non-branded items. Non-branded Choco beans and papadhs contained naphthol yellow. It is concluded here that although majority of the items contained well within the permitted limits of dyes, their uncontrolled and unwise use in the non-branded items will put children at a higher risk of urticaria, angioedema, asthma, atopic dermatitis, food intolerance, genotoxicity, cytotoxicity, and mutagenicity [28, 29].

The concentrations of orange coloured dyes among the analyzed samples (Table 4) revealed sunset yellow being the most common dye used in the branded items. The concentration of the dye in these samples were well within the permitted standard of $300 \mathrm{mg} / \mathrm{kg}$. Among the non-branded items naphthol yellow was found in aniseeds and papadh in higher concentrations. As mentioned earlier naphthol yellow had been phased out quite earlier and the use of this dye in such item is a matter of serious food safety that need to be dealt with strict measures.

Data regarding the concentrations of green dyes (Table 5) revealed that some branded items contained green $\mathrm{S}$ in quite higher concentrations. Similarly, the concentrations of green FCF was found to be high in chocolate beans in a branded sample and that of green $\mathrm{S}$ in a lollipop sample $(213.6 \mathrm{mg} / \mathrm{kg})$. Among the nonbranded items blue FCF was quite higher $(210.6 \mathrm{mg} / \mathrm{kg}$ ) against the permitted 100 $\mathrm{mg} / \mathrm{kg}$ limit. A sample of a candy was found to contain $250.3 \mathrm{mg} \mathrm{kg}^{-1}$ green $\mathrm{S}$ and 256.3 $\mathrm{mg} \mathrm{kg}^{-1}$ brilliant blue FCF against the 100 $\mathrm{mg} \mathrm{kg}^{-1}$ permitted limit in a fruit jelly. The presence of green $\mathrm{S}$ in the analyzed samples is a serious public health concern while the unwise use of permitted dyes is a matter of food safety law implementations. Such confectioneries are mostly consumed by young children and will contribute to compromise their health and may cause some serious diseases. 


\section{Percent Distribution of the Samples}

48

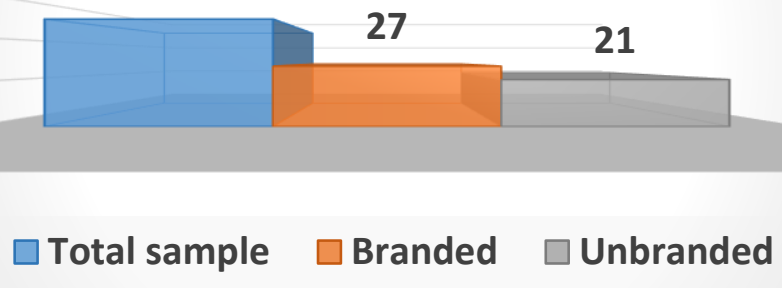

Graph 1. Percent Distribution of the Samples based on labels

Table 1. Summary of the Dyes Identified

\begin{tabular}{|c|c|c|c|c|}
\hline $\begin{array}{c}\text { Dye } \\
\text { Identified }\end{array}$ & $\begin{array}{c}\text { E- } \\
\text { Number }\end{array}$ & Molecular Formula & Approval Status & $\begin{array}{l}\text { Max. Permissible } \\
\text { limit/ADI }\end{array}$ \\
\hline Ponceau 4R & E 124 & $\mathrm{C}_{20} \mathrm{H}_{11} \mathrm{~N}_{2} \mathrm{Na}_{3} \mathrm{O}_{10} \mathrm{~S}_{3}$ & $\begin{array}{l}\text { Approved in EU but under } \\
\text { consideration by FDA }\end{array}$ & $50 \mathrm{mg} / \mathrm{kg} / 0.7 \mathrm{~g} / \mathrm{kg} /$ day \\
\hline $\begin{array}{l}\text { Carmoisine } \\
\text { /Azorubine }\end{array}$ & E 122 & $\mathrm{C}_{20} \mathrm{H}_{12} \mathrm{~N}_{2} \mathrm{Na}_{3} \mathrm{O}_{7} \mathrm{~S}_{2}$ & $\begin{array}{c}\text { Approved in EU, voluntary } \\
\text { phase out in UK, currently } \\
\text { banned in Canada, Japan, } \\
\text { Norway, USA }\end{array}$ & $\begin{array}{c}50 \mathrm{mg} / \mathrm{kg} \\
/ 04 \mathrm{mg} / \mathrm{kg} \text { body } \\
\text { weight/day }\end{array}$ \\
\hline Tartrazine & E 102 & $\mathrm{C}_{16} \mathrm{H}_{9} \mathrm{~N}_{4} \mathrm{Na}_{3} \mathrm{O}_{9} \mathrm{~S}_{2}$ & Approved in USA \& EU & $50 \mathrm{mg} / \mathrm{kg} / 7.5 \mathrm{mg} / \mathrm{kg} / \mathrm{day}$ \\
\hline $\begin{array}{l}\text { Naphthol } \\
\text { Yellow }\end{array}$ & -------- & $\mathrm{C} 10 \mathrm{H} 4 \mathrm{~N}_{2} \mathrm{NaO} 5$ & Banned as food additive & ------------- \\
\hline $\begin{array}{l}\text { Quinoline } \\
\text { Yellow }\end{array}$ & E 104 & $\mathrm{C}_{18} \mathrm{H}_{13} \mathrm{NO}_{5 / 8 / 11} \mathrm{~S}_{1 / 2 / 3} \mathrm{Na}_{1 / 2 / 3}$ & $\begin{array}{c}\text { Approved in EU, voluntary } \\
\text { phase out in UK }\end{array}$ & $0.5 \mathrm{mg} / \mathrm{kg} /$ day \\
\hline $\begin{array}{l}\text { Sunset } \\
\text { Yellow }\end{array}$ & E 110 & $\mathrm{C}_{16} \mathrm{H}_{10} \mathrm{~N}_{2} \mathrm{Na}_{2} \mathrm{O}_{7} \mathrm{~S}_{2}$ & $\begin{array}{l}\text { Approved in EU, Banned } \\
\text { in Norway }\end{array}$ & $50 \mathrm{mg} / \mathrm{kg} / 1 \mathrm{mg} / \mathrm{kg} / \mathrm{day}$ \\
\hline $\begin{array}{l}\text { Brilliant } \\
\text { Blue FCF }\end{array}$ & E 113 & $\mathrm{C}_{37} \mathrm{H}_{34} \mathrm{~N}_{2} \mathrm{Na}_{2} \mathrm{O}_{4} \mathrm{~S}_{3}$ & Approved in USA \& UK & $50 \mathrm{mg} /$ day \\
\hline $\begin{array}{c}\text { Fast Green } \\
\text { FCF } \\
\end{array}$ & E 143 & $\mathrm{C}_{37} \mathrm{H}_{37} \mathrm{~N}_{2} \mathrm{O}_{10} \mathrm{~S}_{3}$ & Banned in UK & \\
\hline Green $\mathrm{S}$ & E 142 & $\mathrm{C}_{27} \mathrm{H}_{25} \mathrm{~N}_{2} \mathrm{NaO}_{7} \mathrm{~S}_{2}$ & $\begin{array}{c}\text { Banned in Canada, USA, } \\
\text { Japan, Norway }\end{array}$ & $50 \mathrm{~m} / \mathrm{kg}$ \\
\hline
\end{tabular}

\section{Summary of Percent Distribution of the Dyes within the Samples}

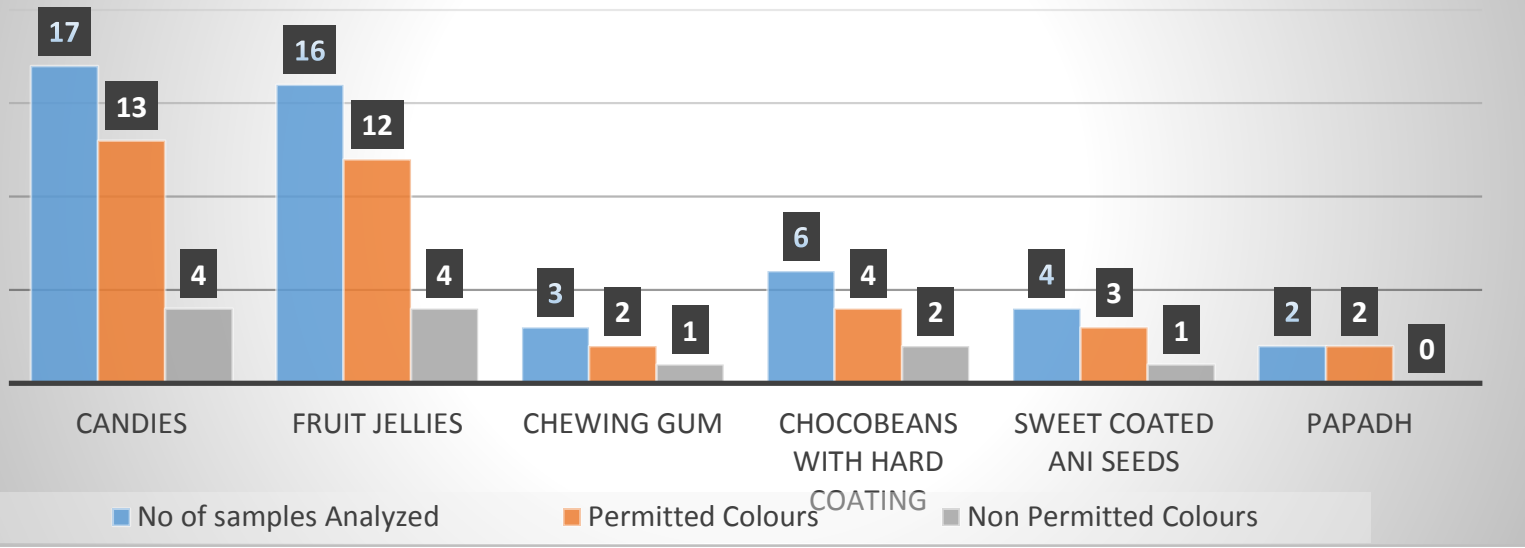

Graph 2. Percent distribution of samples based on permissibility of dyes 


\section{Percent Distribution of Colours in the Sample}

20.9

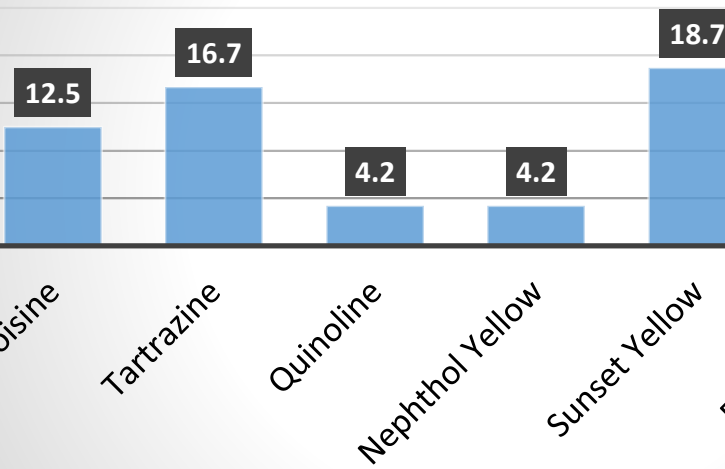

18.7 14.6
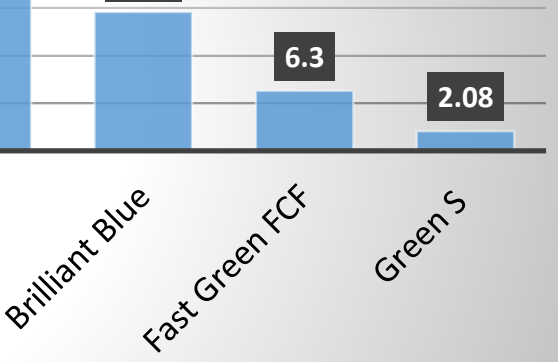

Graph 3. Percent distribution of dyes within the samples

Table 2. Content of Red Dyes in the Selected Confectionery Samples

\begin{tabular}{|c|c|c|c|c|c|}
\hline S\# & Food items & Dye identified & $\chi \max (\mathbf{n m})$ & Conc.mg kg-1 & $\begin{array}{c}\text { Permissible } \\
\text { limits* }\end{array}$ \\
\hline \multicolumn{5}{|c|}{ Branded items } & \\
\hline 1. & Hard Candy & Ponceau 4 R & $507 \mathrm{~nm}$ & $125.4 \pm 1.071$ & \multirow{4}{*}{$300 \mathrm{mg}$} \\
\hline 2 & Hard Candy & Ponceau $4 \mathrm{R}$ & $507 \mathrm{~nm}$ & $126.6 \pm 1.08$ & \\
\hline 3 & $\begin{array}{l}\text { Hard Candy (coloured } \\
\text { syrup in center) }\end{array}$ & Ponceau $4 \mathrm{R}$ & $507 \mathrm{~nm}$ & $153.2 \pm 0.56$ & \\
\hline 4 & Hard Candy & Ponceau $4 \mathrm{R}$ & $507 \mathrm{~nm}$ & $133.8 \pm 0.71$ & \\
\hline 5 & Fruit Jelly & Carmoisine & $516 \mathrm{~nm}$ & $134.7 \pm 0.36$ & -------- \\
\hline 6 & Fruit Jelly & Carmoisine & $516 \mathrm{~nm}$ & $141.0 \pm 1.96$ & --------------- \\
\hline 7 & $\begin{array}{l}\text { Choco beans with hard } \\
\text { coating }\end{array}$ & Carmoisine & $516 \mathrm{~nm}$ & $133.8 \pm 0.39$ & \\
\hline 8 & Chewing gum & Carmoisine & $516 \mathrm{~nm}$ & $114.9 \pm 0.25$ & \\
\hline \multicolumn{5}{|c|}{ Non - Branded Item } & \\
\hline 9 & Hard Candy & Carmoisine & $516 \mathrm{~nm}$ & $337.5 \pm 0.63$ & \\
\hline 10 & $\begin{array}{l}\text { Fruit Jelly } \\
\end{array}$ & Quinoline Yellow & $507 \mathrm{~nm}$ & $144.9 \pm 0.29$ & $100 \mathrm{mg}$ \\
\hline 11 & $\begin{array}{l}\text { Choco beans with hard } \\
\text { coating }\end{array}$ & Ponceau $4 \mathrm{R}$ & $507 \mathrm{~nm}$ & $158.4 \pm 1.19$ & $50 \mathrm{mg}$ \\
\hline 12 & $\begin{array}{l}\text { Choco beans with hard } \\
\text { coating }\end{array}$ & Carmoisine & $516 \mathrm{~nm}$ & $375.0 \pm 0.90$ & $50 \mathrm{mg}$ \\
\hline 13 & Aniseeds (color coated) & Carmoisine & $516 \mathrm{~nm}$ & $364.8 \pm 0.68$ & \\
\hline
\end{tabular}

Table 3. Content of Yellow Dyes with in the Confectionery Samples

\begin{tabular}{|c|c|c|c|c|c|}
\hline S\# & Food items & Dye identified & $\chi \max (\mathbf{n m})$ & Conc.mg kg-1 & $\begin{array}{c}\text { Permissible } \\
\text { limits }^{*}\end{array}$ \\
\hline \multicolumn{6}{|c|}{ Branded items } \\
\hline 1. & Hard Candy & Tartrazine & $425 \mathrm{~nm}$ & $146.7 \pm 0.36$ & $300 \mathrm{mg}$ \\
\hline 5 & Fruit Jelly & $\begin{array}{l}\text { Quinoline } \\
\text { Yellow }\end{array}$ & $410 \mathrm{~nm}$ & $244.5 \pm 0.61$ & ----------- \\
\hline 6 & Fruit Jelly & $\begin{array}{l}\text { Quinoline } \\
\text { Yellow }\end{array}$ & $410 \mathrm{~nm}$ & $181.5 \pm 0.71$ & ---------- \\
\hline 8 & Chewy soft candy & $\begin{array}{l}\text { Quinoline } \\
\text { Yellow }\end{array}$ & $410 \mathrm{~nm}$ & $206.5 \pm 1.02$ & ----------- \\
\hline \multicolumn{6}{|c|}{ Non- Branded Item } \\
\hline 10 & Fruit Jelly & Tartrazine & $425 \mathrm{~nm}$ & $327.2 \pm 1.36$ & $300 \mathrm{mg}$ \\
\hline 11 & Hard candy & Tartrazine & $425 \mathrm{~nm}$ & $287.5 \pm 0.73$ & $300 \mathrm{mg}$ \\
\hline 12 & $\begin{array}{l}\text { Choco beans with hard } \\
\text { coating }\end{array}$ & Naphthol Yellow & $378 \mathrm{~nm}$ & $312.5 \pm 10.43$ & ------- \\
\hline 13 & Papadh & Naphthol Yellow & $378 \mathrm{~nm}$ & $812.5 \pm 21.07$ & ---------- \\
\hline
\end{tabular}


Table 4. Concentrations of Orange Dyes within the Selected Samples

\begin{tabular}{|c|c|c|c|c|c|}
\hline S\# & Food items & Dye identified & $\chi \max (\mathrm{nm})$ & Conc.mg kg-1 & \\
\hline \multicolumn{5}{|c|}{ Branded items } & \\
\hline 1. & Hard Candy & Sun set yellow & $482 \mathrm{~nm}$ & $381.2 \pm 0.03$ & \multirow{8}{*}{$300 \mathrm{mg}$} \\
\hline 2 & $\begin{array}{l}\text { Hard Candy (coloured } \\
\text { syrup in center) }\end{array}$ & Tartrazine & $425 \mathrm{~nm}$ & $244.5 \pm 0.38$ & \\
\hline 3 & Hard Candy & Sunset Yellow & $425 \mathrm{~nm}$ & $238.6 \pm 0.82$ & \\
\hline 4 & Fruit Jelly & $\begin{array}{l}\text { Quinoline } \\
\text { Yellow }\end{array}$ & $425 \mathrm{~nm}$ & $178.9 \pm 0.51$ & \\
\hline 5 & Chewy soft candy & Sunset Yellow & $425 \mathrm{~nm}$ & $119.8 \pm 0.29$ & \\
\hline 6 & Fruit Jelly & $\begin{array}{l}\text { Quinoline } \\
\text { Yellow }\end{array}$ & $425 \mathrm{~nm}$ & $119.5 \pm 0.12$ & \\
\hline 7 & $\begin{array}{l}\text { Choco beans with hard } \\
\text { coating }\end{array}$ & Sunset Yellow & $425 \mathrm{~nm}$ & $214.6 \pm 0.16$ & \\
\hline 8 & Hard Candy & Sunset Yellow & $425 \mathrm{~nm}$ & $214.2 \pm 0.71$ & \\
\hline \multicolumn{5}{|c|}{ Non -Branded Item } & \multirow{4}{*}{$300 \mathrm{mg}$} \\
\hline 9 & Fruit Jelly & $\begin{array}{l}\text { Quinoline } \\
\text { Yellow }\end{array}$ & $425 \mathrm{~nm}$ & $300.6 \pm 1.20$ & \\
\hline 10 & Fruit Jelly & $\begin{array}{l}\text { Quinoline } \\
\text { Yellow }\end{array}$ & $425 \mathrm{~nm}$ & $254.5 \pm 0.71$ & \\
\hline 11 & $\begin{array}{l}\text { Choco beans with hard } \\
\text { coating }\end{array}$ & Sunset Yellow & $425 \mathrm{~nm}$ & $290.5 \pm 1.84$ & \\
\hline \multirow[t]{2}{*}{13} & Aniseeds (color coated) & Naphthol Yellow & $378 \mathrm{~nm}$ & $219.8 \pm 0.44$ & \\
\hline & Papadh & Naphthol Yellow & $378 \mathrm{~nm}$ & $314.5 \pm 1.36$ & \\
\hline
\end{tabular}

Table 5. Content of Green Dyes in the Confectionery Samples

\begin{tabular}{|c|c|c|c|c|c|}
\hline S\# & Food items & Dye identified & $\chi \max (\mathbf{n m})$ & Conc.mg kg ${ }^{-1}$ & $\begin{array}{c}\text { Permissible } \\
\text { limits* }\end{array}$ \\
\hline \multicolumn{6}{|c|}{ Branded items } \\
\hline 1. & Fruit Jelly & Green FCF & $624 n$ & $327.0 \pm 1.28$ & 400 \\
\hline 5 & Lolli pop & Green S & $640 \mathrm{~nm}$ & $213.6 \pm 0.74$ & --------- \\
\hline 6 & Aniseed & Green FCF & $624 \mathrm{~nm}$ & $378.2 \pm 1.05$ & 100 \\
\hline \multirow[t]{4}{*}{8} & Fruit Jelly & Green S & $640 \mathrm{~nm}$ & $141.3 \pm 0.36$ & 400 \\
\hline & Fruit Jelly & $\begin{array}{c}\text { Brilliant Blue } \\
\text { FCF }\end{array}$ & $630 \mathrm{~nm}$ & $189.6 \pm 0.91$ & $300 \mathrm{mg}$ \\
\hline & Fruit Jelly & $\begin{array}{l}\text { Brilliant Blue } \\
\text { FCF }\end{array}$ & $630 \mathrm{~nm}$ & $141.3 \pm 0.34$ & $100 \mathrm{mg}$ \\
\hline & $\begin{array}{l}\text { Choco beans with hard } \\
\text { coating }\end{array}$ & Green FCF & $624 \mathrm{~nm}$ & $158.5 \pm 0.26$ & 100 \\
\hline \multicolumn{6}{|c|}{ Non -Branded Item } \\
\hline 10 & Fruit Jelly & $\begin{array}{c}\text { Brilliant Blue } \\
\text { FCF } \\
\end{array}$ & $630 \mathrm{~nm}$ & $256.5 \pm 0.16$ & $100 \mathrm{mg}$ \\
\hline 11 & Hard candy & $\begin{array}{c}\text { Brilliant Blue } \\
\text { FCF }\end{array}$ & $630 \mathrm{~nm}$ & $144.5 \pm 0.28$ & 300 \\
\hline \multirow[t]{3}{*}{12} & Chewing gum & Green FCF & $624 \mathrm{~nm}$ & $144.5 \pm 0.93$ & 300 \\
\hline & Hard Candy & Green S & $640 \mathrm{~nm}$ & $250.3 \pm 0.25$ & \\
\hline & $\begin{array}{l}\text { Choco beans with hard } \\
\text { coating }\end{array}$ & $\begin{array}{l}\text { Brilliant Blue } \\
\text { FCF }\end{array}$ & $630 \mathrm{~nm}$ & $210.6 \pm .017$ & 100 \\
\hline \multirow[t]{2}{*}{13} & Hard Candy & Green S & $640 \mathrm{~nm}$ & $68.5 \pm 0.38$ & 100 \\
\hline & Ani seeds & $\begin{array}{c}\text { Brilliant Blue } \\
\text { FCF }\end{array}$ & $630 \mathrm{~nm}$ & $114.5 \pm 0.96$ & 100 \\
\hline
\end{tabular}

\section{Conclusion}

The current introductory study found excessive use of permitted food colours in some confectioneries while some contained nonpermitted food colours. Therefore, there is a dire need to create awareness among the 
masses at different levels about the consumption of synthetic food colours and their toxic effects and health hazards particularly young children. Consequently, a systematic approach must be carried out within the country to establish rules and regulations to prevent malpractices of synthetic food colour adulteration, proper labelling of confectionaries, supervising the permissible level of permitted synthetic colours, and to guard against the use of nonpermitted colours in all food items to assure food safety and quality. This study also highlights the requirement of a governing authority to introduce global regulations on food safety within the country.

\section{Authors' contributions}

Conceived and designed the experiments: $\mathrm{F}$ Ghaffar, Performed the experiments: F Ghaffar, F Tauqeer \& R Rauf, Analyzed the data: F Ghaffar \& F Inayat, Contributed reagents/ materials/ analysis tools: $\mathrm{F}$ Ghaffar \& F Inayat, Wrote the paper: F Ghaffar.

\section{References}

1. Alves PV, Brum DM, Branco de Andrade EC \& Pereira Netto AD (2008). Determination of synthetic dyes in selected foodstuffs by high performance liquid chromatography with UV-DAD detection. Food Chem 107(1): 489-496.

2. Yadav DS, Jaiswal S, Mishra MK \& Gupta AK (2016). Analysis of nonpermitted dyes in bakery and dairy products for forensic consideration. IJDR 6: 8775-8779.

3. Lok KYW, Chung YW, Benzie IFF \& Woo J (2011). Synthetic colourings of some snack foods consumed by primary school children aged 8-9 years in Hong Kong. Food Additives and Contaminants- Part B 4(3): 162-167.

4. Rajapaksha GKM, Wansapala MAJ \& Silva ABG (2017). Detection of synthetic colours in selected foods \& beverages available in Colombo district, Sri Lanka. Int J Sci Res 6(5): 801-808.
5. Rao P, Bhat RV, Sudershan RV \& Prasanna Krishna T (2005). Consumption of synthetic food colours during festivals in Hyderabad, India. Brit Food J 107(5): 276-284.

6. Ashfaq $\mathrm{N} \&$ Masud $\mathrm{T}$ (2002). Surveillance on artifical colours in different ready to eat foods. Pak J Nutr 1(5): 223-225.

7. IFIC. (2011). International Food Information Council. Foundation Food Survey

8. Hathcock JN \& Rader JI (2003). Aditivos, contaminantes e toxinas naturais de alimentos in Tratado de Nutric_ao Moderna na Sau de e na Doenc_a, 9th edition Editora Manole Ltda, Sao Paulo, Brazil.

9. NIS (2002). Permitted Artificial Colours. $4^{\text {Th }}$ Edn. Food \& Drug Administration, Tehran, pp 147.

10. Rezaei M, Abadi FS, \& Sharifi Z (2014). Assessment of synthetic dyes in food stuffs produced in confectioneries and restaurants in Arak, Iran. Thrita 3(4).

11. Farzianpour F, Khaniki GJ, Younesian M, Ghahferkhi BB, Sadeghi M \& Hosseini S (2013). Evaluation of food color consumption and determining color type by thin layer chromatography. Am J Appl Sci 10(2): 172-178.

12. Rao P \& Sudershan RV (2008). Risk assessment of synthetic food colours: a case study in Hyderabad, India. Int J Food Saf Nutr Publ Health 1(1): 6887.

13. Downham A \& Collins P (2000). Colouring our foods in the last and next millennium. Int J Food Sci Tech 35(1): 5-22.

14. Schuster R \& Gratzfeld-Hüsgen A (1995). Analysis of Synthetic Dyes in Food Samples by Capillary Zone Electrophoresis, HP Company, Palo Alto, CA, USA.

15. Zahra N, Alim-un-Nisa ZF, Kalim I \& Saeed K (2015). Identification of synthetic food dyes in beverages by 
thin layer chromatography. PJFS 25(4): 178-181.

16. Saleem N, Nasreen UZ \& Ismat IK (2013). Survey on the use of synthetic food colors in food samples procured from different educational institutes of Karachi city. J Trop Life Sci 1(3): 1-7.

17. Hinton DM (2000). US FDA "red book II" immunotoxicity testing guidelines and research in immune toxicity evaluation of food chemicals and new food proteins. Toxicol Pathol 28: 467478

18. Geoffrey B A \& Felix MB (1991). Canthaxanthin and the eye. A critical ocular toxicologic assessment. Cut Ocular Toxicol 10: 115-155

19. Bachalla N (2016). Identification of synthetic food colors adulteration by paper chromatography and spectrophotometric methods. IAIM 3(6): 182-191.

20. Nath PP, Sarkar K, Tarafder P, Mondal M, Das K \& Paul G. (2015). Practice of using metanil yellow as food colour to process food in unorganized sector of west bengal-a case study. Int Food Res J 22(4): 1424-1428.

21. Shinde A \& Shinde M (2013). Adulteration of food by synthetic colours and safe natural colours. Search and Res 1(1): 21-23.

22. Rowe KS \& Rowe KJ (1994). Synthetic food coloring and behavior: a dose response effect in a doubleblind, placebo-controlled, repeated- measures study. $J$ of Pediatr 125(5): 691-698.

23. Tuormaa TE (1994). The adverse effects of food additives on health: a review of the literature with a special emphasis on childhood hyperactivity. J Orthomol Med 9(4): 225-243.

24. Das A \& Mukherjee A (2004). Genotoxicity testing of the food colours amaranth and tartrazine. Int $J$ Hum Genet 4(4): 277-280.

25. Dilrukshi PGT, Munasinghe $\mathrm{HH}$,_Silva ABG, \& De Silva PGSM (2019). Identification of synthetic food colours in selected confectioneries and beverages in Jaffna District, Sri Lanka. J Food Qual.

26. Kobylewski S \& Jacobson MF (2010). Food dyes a rainbow of Risks. Center for science in the public interest. Connecticut Avenue, NW, Suite 300 Washington, DC.

27. Soares B, Araujo T, Ramos J \& Pinto L (2015). Effects on DNA repair in human lymphocytes exposed to the food dye tartrazine yellow. Anticancer Res 35(3): 1465-74.

28. Purba MK, Agrawal N, \& Shukla SK (2015). Detection of non-permitted food colors in edibles. JFS 4: 125-131.

29. Kobylewski S \& Jacobson MF (2010). Food dyes a rainbow of Risks. Center for science in the public interest. Connecticut Avenue, NW, Suite 300 Washington, DC. 